\title{
Factors and Criteria to Quantify the Bioproduction Potential of Coastal Areas and Presentation of a Simple Operational Index of Biological Value (IBV) for Coastal Management
}

\author{
Lars Håkanson ${ }^{*}$
}

Department of Earth Sciences, Uppsala University, Villav. 16, SE-752 36 Uppsala, Sweden

\begin{abstract}
There are major differences in the bioproduction potential of different coastal areas. The aim of this work is to review and discuss simple, operational criteria related to the bioproduction potential of coastal areas and to present and motivate an Index of Biological Value (IBV) for coastal management. This index is based on two key variables, which can be determined easily from bathymetric maps and data from standard monitoring programs: (1) the bottom area of the coast above the Secchi depth and (2) the topographical openness (or exposure) of the coastal area. The exposure is defined by the ratio between the section area of the coast and the enclosed coastal area. The boundaries of the coastal area should not be defined in an arbitrary manner but according to the topographical bottleneck method so that the exposure attains a minimum value. IBV is meant to be used to identify coastal areas with a high production potential so that preservation plans and remedial actions can be directed to such areas in a cost-efficient manner. Applying the index using a dataset including 478 coastal areas from the Baltic Sea, there were 5 (1\%) extremely productive coastal areas (IBV>50), $43(9 \%)$ very productive coastal areas $(25<\mathrm{IBV}<50), 209(43.7 \%)$ productive coastal areas $(10<\mathrm{IBV}<25), 214(63.0 \%)$ moderately productive coastal areas $(1<\mathrm{IBV}<10)$ and $7(1.5 \%)$ low-productive coastal areas $(\mathrm{IBV}<1)$.
\end{abstract}

Keywords: Coastal areas, ecosystem, bioproduction, index, management, Secchi depth, morphometry, exposure.

\section{INTRODUCTION}

The coastal zone may be regarded as a "pantry and a nursery" for the sea. It has been demonstrated that shallow coastal areas can have a bioproduction many times higher than the most productive areas on land [1]; all three functional groups of primary producers - phytoplankton, benthic algae and macrophytes - are present in shallow coastal areas (but not in deep open water areas); and where there is a high primary production, there is also generally a high secondary production of zooplankton, zoobenthos and fish $[2,3]$. The coastal zone is also a zone of conflicts where many different users place different demands and apply different criteria to set the value of the coast [4-8].

Water quality indices and trophic level classifications may be useful tools for enhancing communications among natural scientists, water managers, economists, policymakers and/or the general public. A wide variety of indices and bioindicators for coastal areas have emerged during recent years $[9,10]$. The index TRIX (TRophic IndeX) was described by [11] and is also included in Italian legislation [12]. TRIX provides a value indicating increasing trophic level (or state). It is based on the concentration of chlorophyll-a $(\mathrm{Chl}$ in $\mu \mathrm{g} / \mathrm{l})$, the oxygen saturation in the deep-water zone $\left(\mathrm{O}_{2} \mathrm{Sat}\right.$ in $\%$ ), total-P concentration (TP in $\mu \mathrm{g} / \mathrm{l})$ and total-N concentration ( $\mathrm{TN}$ in $\mu \mathrm{g} / \mathrm{l})$.

Paper [10] presented a general classification system related to differences in trophic level (oligotrophic,

*Address correspondence to this author at the Department of Earth Sciences, Uppsala University, Villav. 16, SE-752 36 Uppsala, Sweden;

E-mail: Lars.Hakanson@geo.uu.se mesotrophic, eutrophic and hypertrophic systems) for systems characterized by different salinities. That classification system targets on the following bioindicators, which are meant to reflect important structural and functional aspects of aquatic ecosystems and seasonal median (characteristic) values for entire defined areas (the ecosystem scale) and not conditions at individual sites or data from shorter time periods: Secchi depth (as a standard measure of water clarity), chlorophyll-a concentrations (a measure of phytoplankton biomass), the oxygen saturation in the deep-water zone (an indicator reflecting sedimentation, oxygen consumption, oxygen concentrations and the habitat conditions for zoobenthos, an important functional group) and the macrophyte cover (an important variable for the bioproduction potential, including fish production of coastal areas). These bioindicators can be predicted by practically useful models and they are regulated by a set of abiotic factors, such as salinity, nutrient concentrations ( $\mathrm{N}$ and $\mathrm{P})$, coastal morphometry and water exchange.

Numerous papers and books deal with coastal eutrophication [12-23]. The aim here is not to review aspects of eutrophication at different temporal and spatial scales. Instead, the focus is set at the ecosystem scale and the idea is to focus on criteria regulating the bioproduction potential of coastal areas. The objective is to discuss, motivate and present a simple operational index of biological production potential or biological "value". To be operational in coastal management, the requested index should be based on readily accessible parameters, which can be determined from bathymetric maps and data from regular monitoring programs. In contexts of coastal management, the primary interest is not on sitespecific conditions ("the sampling bottle"), but at the ecosystem level. That perspective should be of main interest when 
questions are posed concerning the status of larger water bodies (ecosystems), and the threat to coastal systems, criteria to protect coastal areas and strategies for remedial actions to improve the conditions in such systems.

The next section will discuss criteria to determine coastal areas boundaries. A following section will review fundamental aspects regulating the bioproduction potential of coastal ecosystems and from those results, the final section will present and apply the requested Index of Biological Value (IBV).

The results presented in this study should fit nicely into the coastal area classifications discussed within the ECWater Framework Directive [24], where criteria and tools such as those discussed in this paper are requested.

\section{DEFINING COASTAL AREA BOUNDARIES}

A very important question for this work and for many aspects of coastal management concerns the definition of coastal ecosystem boundaries. The question is where to place the limitation lines toward the sea and/or adjacent coastal areas. It is crucial to use a technique that provides an ecologically meaningful and practically useful definition of the coastal ecosystem. How should one define this area so that

\section{A. Open coast}

\section{Dominated by coarse and mixed sediments}

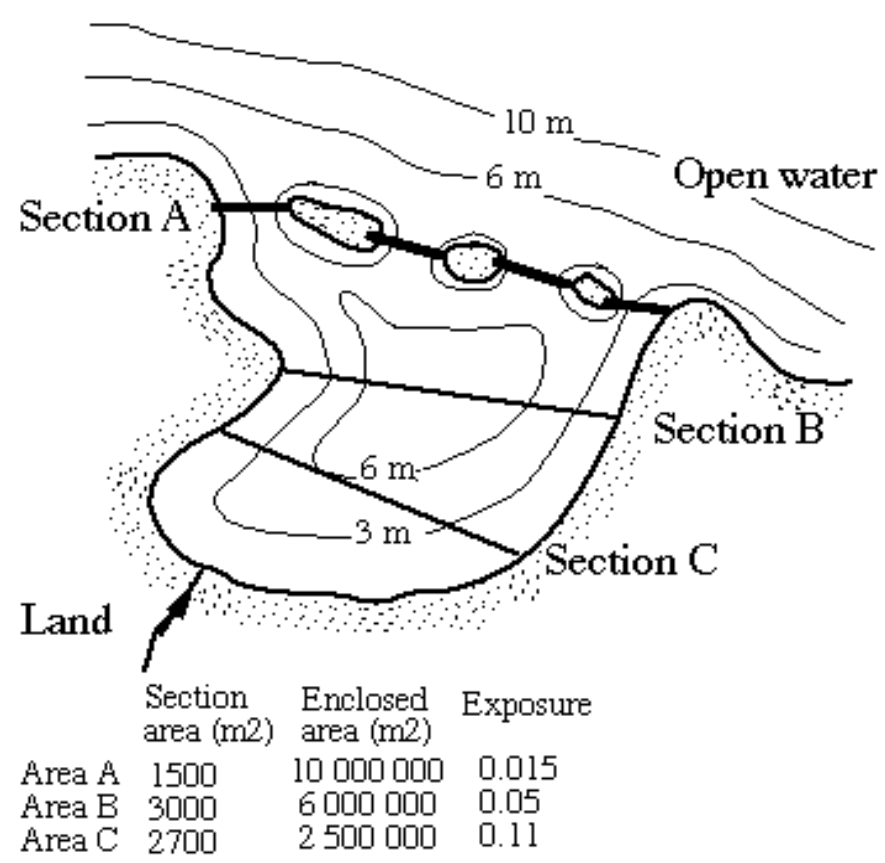

parameters, such as the mean depth, coastal area, volume and the bioproduction potential can be determined in a simple, operational, objective and relevant manner? Arbitrary borderlines can be drawn in many ways and the mean depths of such areas would be devoid of meaning in relation to bioindicators or the target index discussed in this work. The approach used here (from [25]) assumes that the borderlines are drawn at the topographical bottlenecks so that the exposure (Ex) of the coast from winds and waves from the open sea is minimized (Fig. 1). The exposure of the coastal area is the ratio between the section area and the enclosed coastal area $(E x=100 \cdot A t / A r e a$, where At $=$ the total section area or the opening area towards the sea in $\mathrm{km}^{2}$ and Area $=$ the coastal area in $\mathrm{km}^{2}$ ). It is easy to use the Ex-value as a tool to test different alternative borderlines (there are three examples, $\mathbf{A}$, $\mathbf{B}$ and $\mathbf{C}$ in Fig. (1)) and define the coastal ecosystem where the Ex-value is minimal. For open coastal areas, a significant part of the fine materials suspended in the water can "escape" from the coastal area to the sea or to surrounding coastal areas. This is not the case for more closed coastal lagoons (Fig. 1, right).

Once the coastal area is defined, one can also determine important variables for coastal management, such as the

\section{B. Enclosed lagoon Dominated by fine sediments}

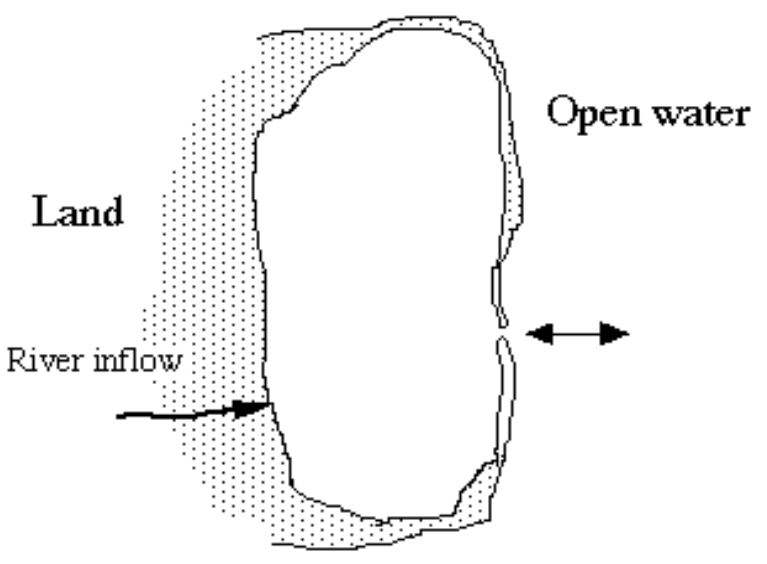

$$
\begin{aligned}
& \text { Section area }=15 \mathrm{~m} 2 \\
& \text { Enclosed area }=10 \text { 000 } 000 \mathrm{~m} 2 \\
& \text { Exposure = } 0.00015
\end{aligned}
$$

\author{
To define the boundary lines for a given coastal area: \\ Minimize the exposure, $\mathrm{Ex}=100 \mathrm{~A} \cdot \mathrm{t} A$ \\ At = section area (m2) \\ A = enclosed coastal area (m2)
}

Fig. (1). Schematical illustration of the topographical bottleneck approach to determine the boundary lines for open coastal systems. The coastal ecosystem is defined by the borderline marked A, which gives a minimum exposure (Ex). To define the boundary line for, e.g., lagoons is generally quite straightforward. 
coastal volume (regulating the concentration of any given substance), important morphometric parameters for internal fluxes, such as the mean depth and the water surface area, key variables regulating the water exchange between the coast and the sea, such as the volume and the section area. This method of defining coastal areas also opens a possibility to use empirical models to estimate, e.g., the theoretical water retention times of the surface water and the deep water, and the bottom dynamic conditions (regulating sedimentation, resuspension and diffusion) from morphometrical parameters [26].

\section{CRITERIA FOR BIOLOGICAL VALUE}

\section{Background Information}

In Fig. (2), which gives a compilation of basic concepts and definitions related to bottom fauna and flora, it is stressed that most benthic algae, macrophytes and zoobenthos appear at a depth smaller than the Secchi depth. This area is generally well oxygenated and has a high bioproduction potential, since all three functional groups of primary producers, phytoplankton, benthic algae and macrophytes, are present in such areas. Where there is a high primary production, there is also generally a high secondary production [27]. Fig. (3) illustrates schematically that different coastal areas (moderately exposed coasts, sheltered, exposed and vegetation-dominated coasts) are dominated by different sediments types. Since the sediments constitute the habitat for the benthic flora and fauna, different coastal areas will also be dominated by different species and functional groups [31].

\section{Coast Type - Exposure and Bioproduction Potential}

It has been demonstrated (Fig. 4) that shallow coastal areas can have a very high bioproduction capacity [1]. From

\section{Zoobenthos, benthic algae and macrophytes}

- Size criteria: macro-, meso-, and meio-benthos

- Feeding criteria:

Shredders

Collectors

Scrapers

Predators

Filter feeders
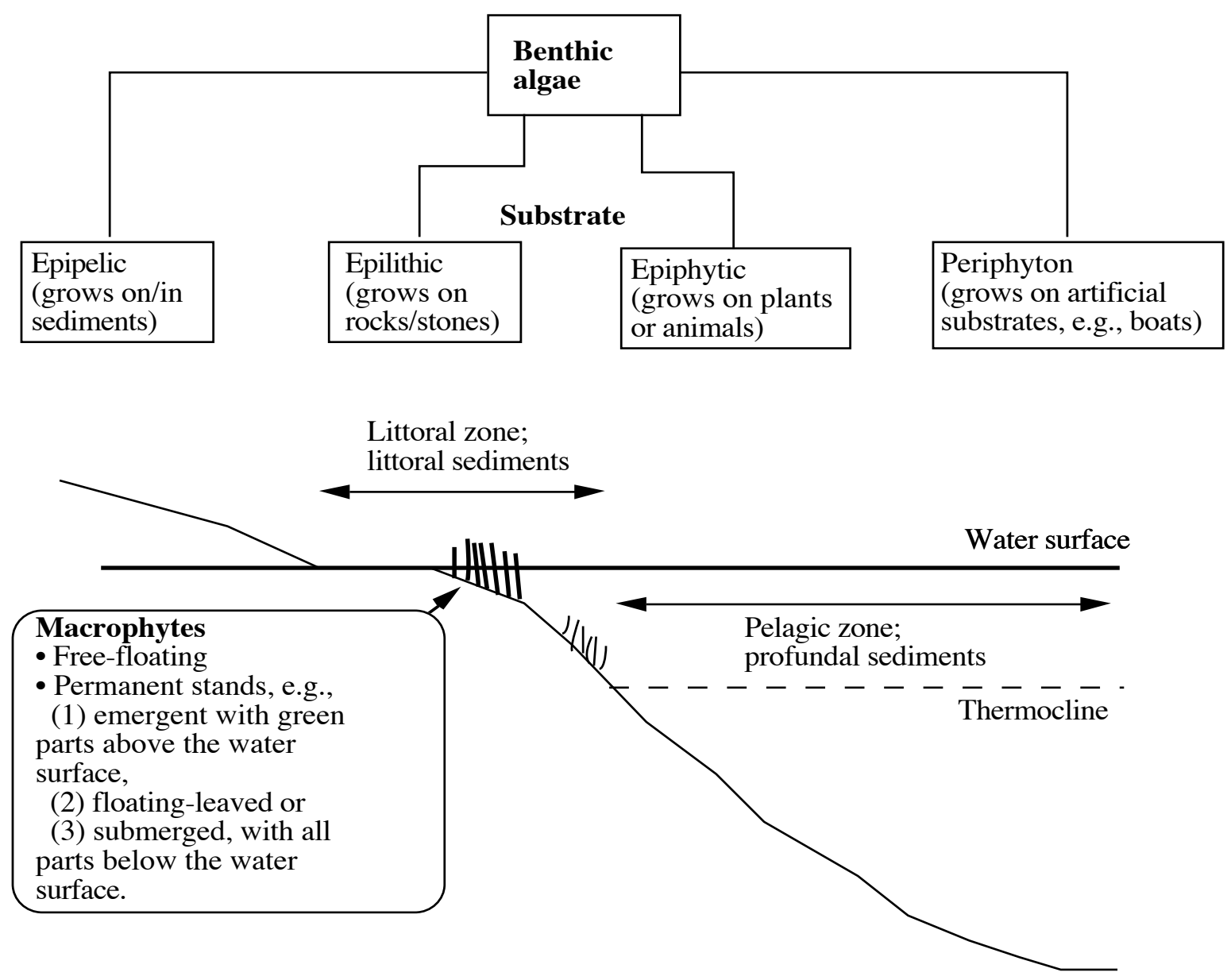

Fig. (2). Concepts related to zoobenthos, benthic algae and macrophytes (see [28, 29]). 

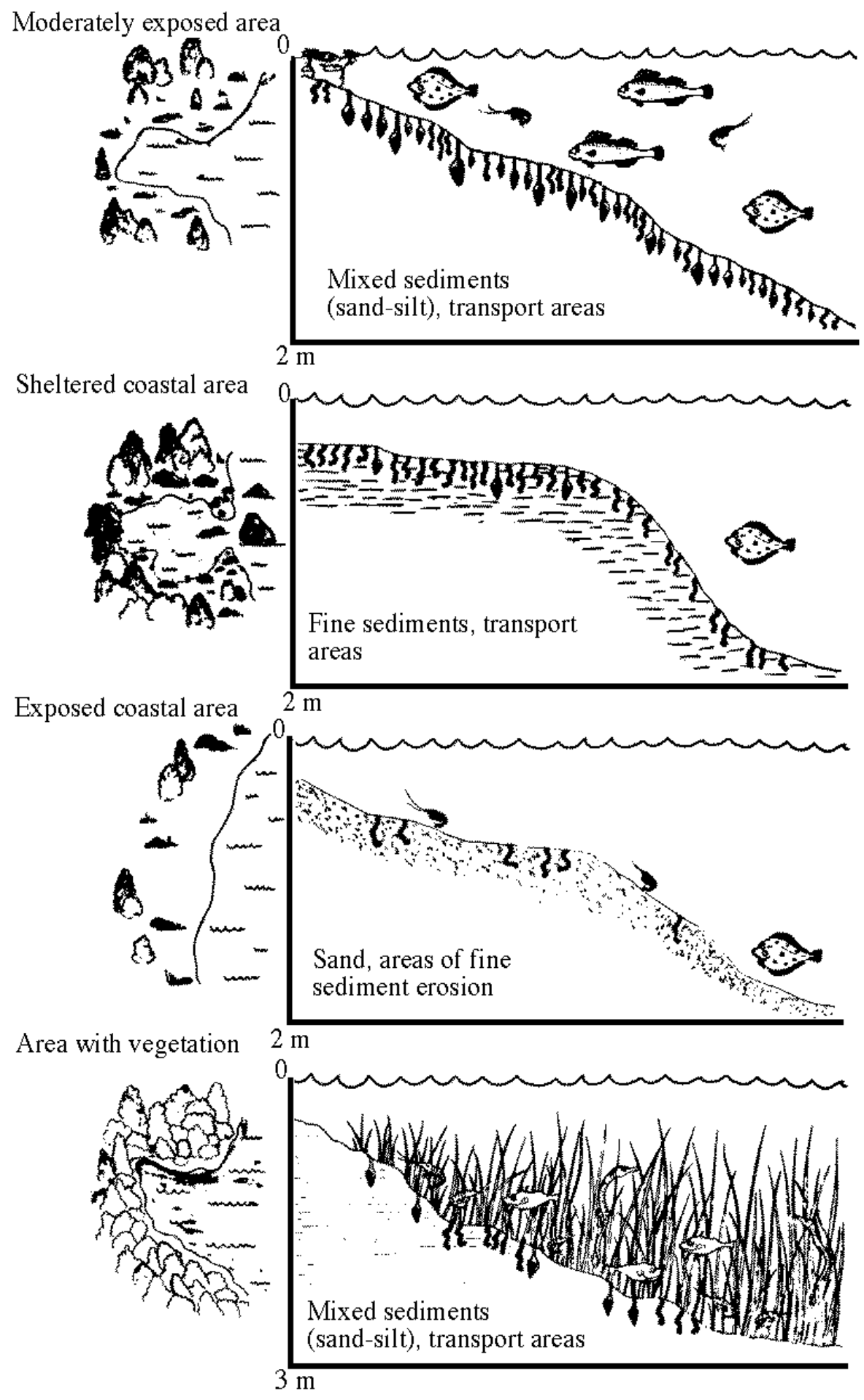

Fig. (3). Illustration of some typical coastal areas with a high production capacity and a high "biological value" (from [30]).

Fig. (4), one can note that at water depths larger than $15 \mathrm{~m}$, one can generally set the production capacity (or turnover rate $=\mathrm{PR} / \mathrm{BM}, \mathrm{PR}=$ production in $\mathrm{kg} /$ time and $\mathrm{BM}=$ biomass in $\mathrm{kg}$ ) of the infauna (i.e., animals $>1 \mathrm{~mm}$ living in the sediments) to be about 1 (1/year). At water depths of $3-15$ $\mathrm{m}, \mathrm{PR} / \mathrm{BM}$ is generally between 1 and 3 . At water depths smaller than $3 \mathrm{~m}$, it is important also to consider the sediment type, the habitat for the infauna.
Coastal areas with a large percentage of the bottom above the Secchi depth, i.e., the water depth down to which most macrophytes may be found and where the production and biomass of benthic algae and zoobenthos may be very high, has a high bioproduction, a high "biological value" and are, hence, target areas in contexts of coastal protection. This is also exemplified by the results given in Fig. (5), which gives the relationship between the biomass of the mobile epifauna and water depth from a coastal area on the Swedish west coast (salinity about $22 \mathrm{psu}$ ). 


\section{Biological "value" of the coast}

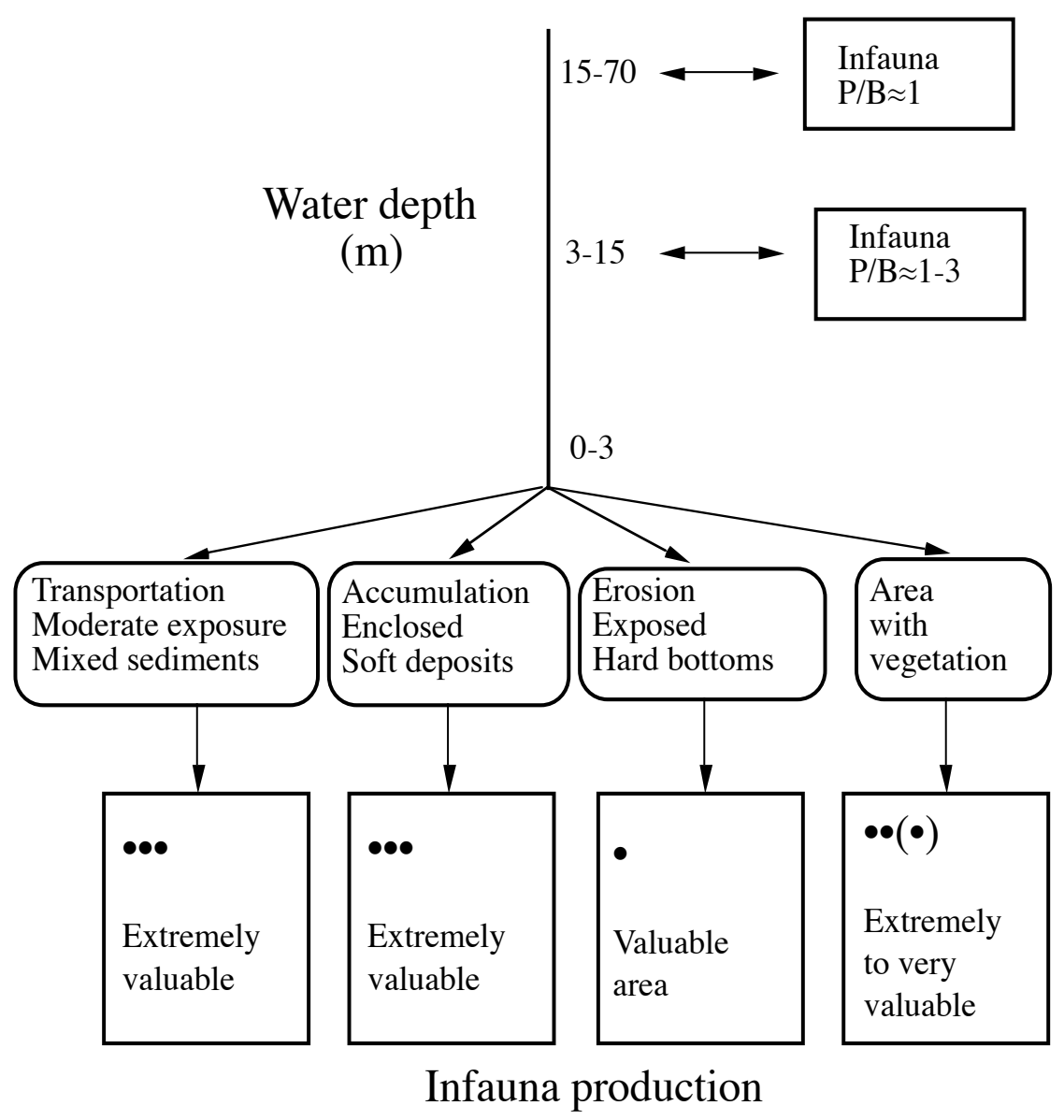

Fig. (4). Criteria to estimate the production potential (PR/BM; PR = production; BM = biomass; PR/BM in years) or "value" of Baltic coastal areas. Modified from [30]. At water depths $>3 \mathrm{~m}$, the production potential is generally low; at water depth $<3 \mathrm{~m}$, the production potential is generally high and depends on the exposure and the bottom substrate. Note that these data exemplify conditions along the Swedish coastal zone.

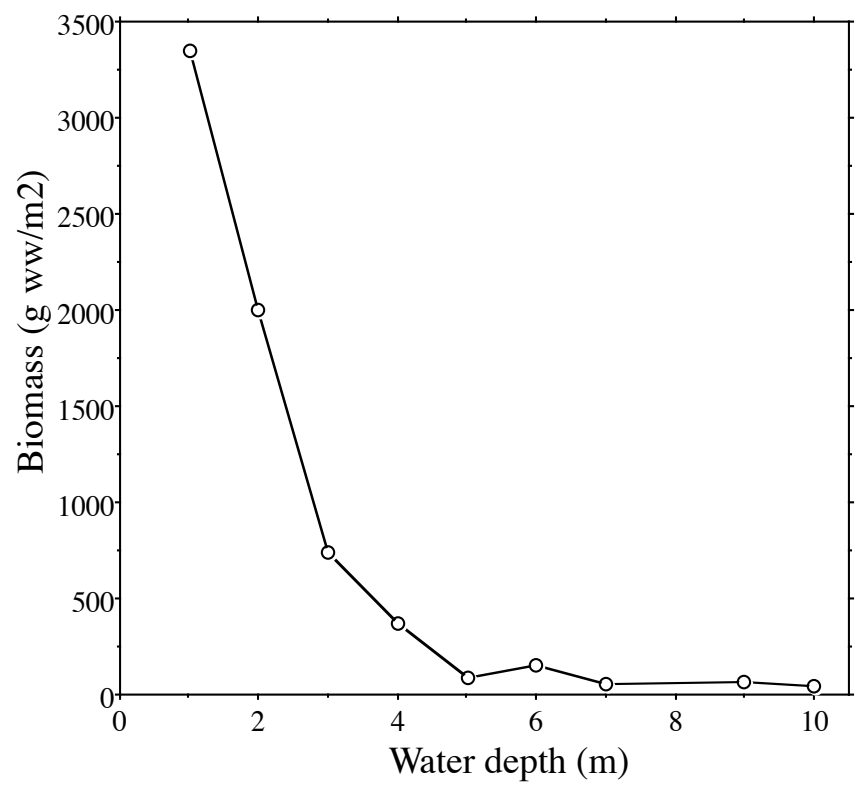

Fig. (5). The relationship between biomass of mobile epifauna ( $>$ $0.5 \mathrm{~mm})$ in gram per $\mathrm{m}^{2}$ and water depth at the sampling sites at Tylösand (on the Swedish west coast; data from [34].

\section{Coastal Form and Bioproduction Potential}

The theoretical wave base may be defined from the ETAdiagram (erosion-transport-accumulation; from [32]). Fig. (6) gives, the relationship between the effective fetch, a measure of the free water surface over which the winds can influence the wave characteristics (speed, height, length and orbital velocity) and the prevailing bottom dynamic conditions. The ETA-diagram separates the erosion areas (dominated by coarse deposits, such as sand, gravel and rocks), from the transportation areas, with discontinuous sedimentation of fine materials (and mixed fine and coarse sediments), from the accumulation areas, with continuous sedimentation of fine suspended particles (and fine sediments). The prerequisites for the benthic production, including the oxic conditions, are generally very different between these three functional zones. The theoretical wave base (separating the $\mathrm{T}$ areas from the A-areas) for open coastal areas is generally at a lower depth than the value given by the equation in Fig. (6) for closed lagoons or lakes. The theoretical wave base in open coastal areas may be estimated using an algorithm given by [33]. If the mean effective fetch (in $\mathrm{km}$ ) for an entire lagoon is set equal to the $\sqrt{\text { Area }}\left(\right.$ Area in $\mathrm{km}^{2}$ ), this ap- 


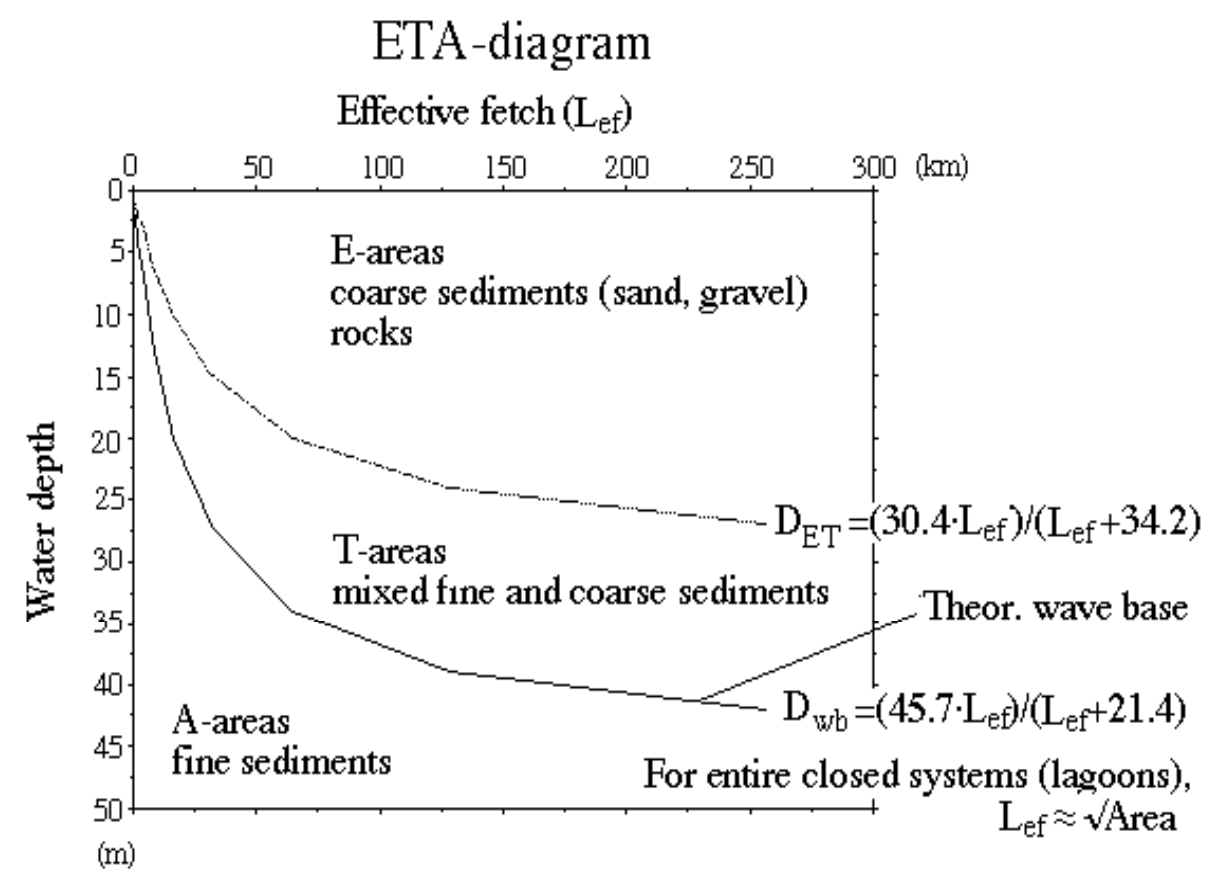

Fig. (6). The ETA-diagram (Erosion-Transportation-Accumulation; for more information, see [32] illustrating the relationship between effective fetch, water depth, bottom dynamic conditions and sediment type.

proach gives one value for the theoretical wave base related to the water surface area of the system.

The form of the coastal areas (i.e., the depth-area characteristics) may be described quantitatively by the volume development (= the form factor, $\mathrm{Vd}$, dimensionless), which is defined by the ratio between the water volume and the volume of a cone, with a base equal to the water surface area (A in $\mathrm{km}^{2}$ ) and with a height equal to the maximum depth (Dmax in $\mathrm{m}$ ). The form of the coast is important, e.g., for the growth of macrophytes and benthic algae and for resuspension. Fig. (7) illustrates, relative hypsographic curves for systems with different Vd-values and also simple bathymetric interpretations of the two most extreme forms (a convex and a concave form). Fig. (8) provides, one step further in the search for an index of biological value. This figure gives four relative hypsographic curves. Coast 1 has a large percentage of the bottom above the Secchi depth, which is the water depth indicating the depth of the photic zone where macrophytes may be found and where the production and biomass of benthic algae and zoobenthos may be very high. Coast 4 has only a small percentage of the bottom area above the Secchi depth, and is likely to have a lower benthic production.

From this, one can conclude that the larger the area of the bottom above the Secchi depth, Asec, the higher the potential bioproduction. Coastal areas with a high bioproduction potential should generally be more important to protect and preserve than less productive areas. In coastal areas which a large fraction of the bottom area above the Secchi depth, one should be particularity careful not to build marinas, harbours and/or emit contaminants (see [30]).

So, the Secchi depth is a key factor in this context. The Secchi depth is also a standard variable in water management. Many factors are known to influence the Secchi depth [35-39]. Secchi depth depends on, (1) autochthonous produc- tion (the amount of plankton, detritus, etc. in the water; more plankton, etc. mean a lower Secchi depth); (2) allochthonous materials (from tributaries); and (3) the amount of resuspended material [26]. These factors are not independent: High sedimentation leads to high amounts of resuspendable materials; high resuspension leads to high internal loading of nutrients and increased production; a high amount of coloured substances in estuaries means a smaller photic zone and a lower production; a high input of allochthonous substances and a high production would mean a high sedimentation, etc. The empirical relationship between Secchi depth and chlorophyll-a largely depends on the chlorophyll-a concentration co-varying with the total amount of suspended particles [40, 41]. Fig. (9) shows. the logical relationship between the Secchi depth, the concentration of suspended particulate matter (SPM) and salinity.

Several studies have also quantified and ranked variables of significance to predict how Secchi depths vary among water systems $[4,42]$. One can conclude that there is generally a significant logical and negative relationships between Secchi depth and nutrient concentrations, chlorophyll and sedimentation - the higher the bioproduction, the more suspended particulate matter (SPM), the higher the sedimentation and the lower the Secchi depth. There is also a significant positive relationship between salinity and Secchi depth - the higher the salinity, the clearer the water. Suspended particles will settle out on the bottom and the organic fraction will be subject to bacterial decomposition (= mineralization). This will influence the oxygen concentration in the sediments and hence also the survival of zoobenthos, an important food for fish. SPM influences primary production of phytoplankton, benthic algae, macroalgae and macrophytes, the production and biomass of bacterioplankton, and hence also the secondary production, e.g., of zooplankton, zoobenthos and fish [26]. 


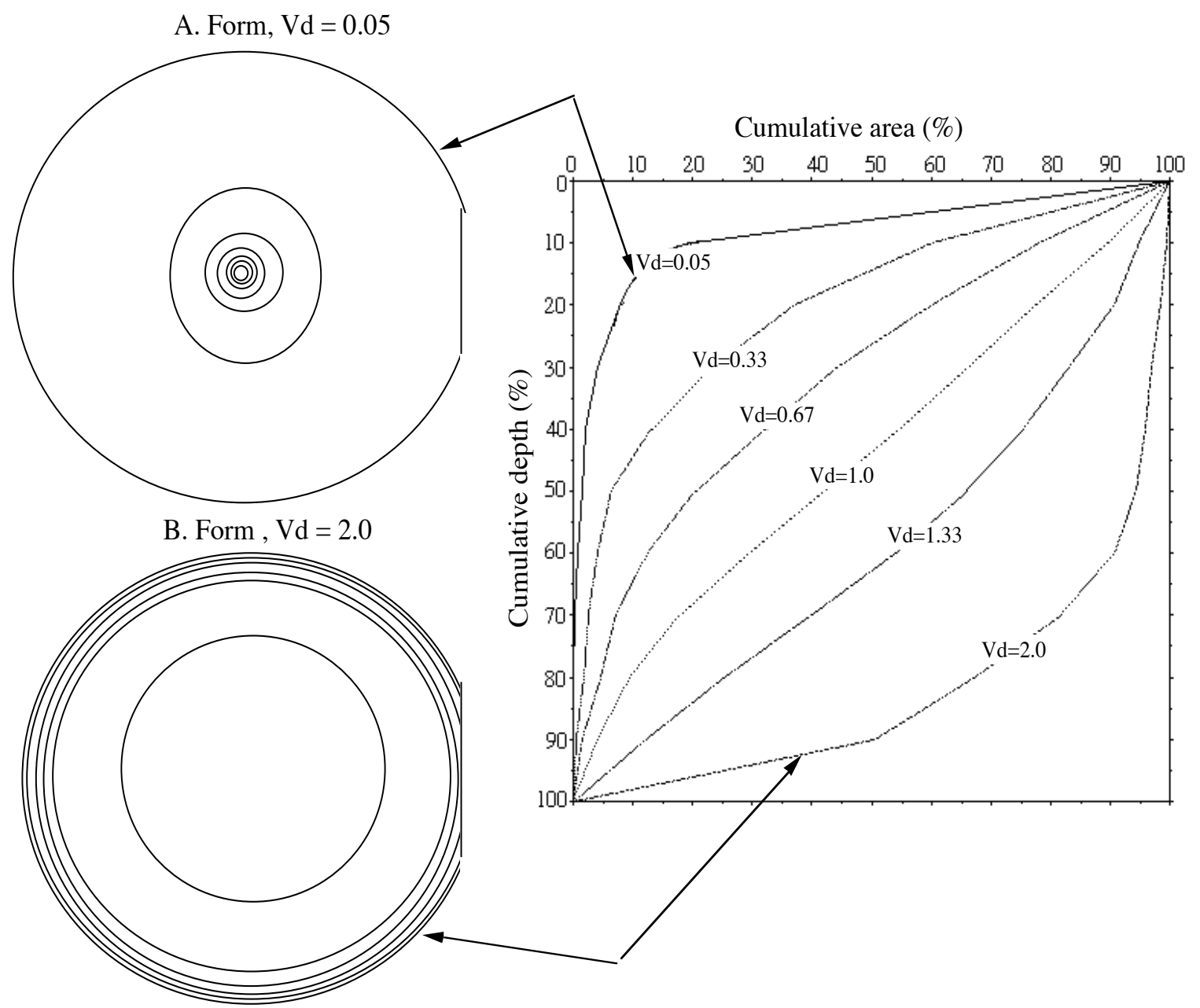

Fig. (7). Schematical bathymetrical illustration of two the coastal areas, (A) is very convex with an Vd-value (form factor, Vd $=0.05)$ and (B) the other is very concave $(\mathrm{Vd}=2.0)$.

\section{DEFINITION OF AN INDEX OF BIOLOGICAL VALUE (IBV)}

From this, one can conclude (1) that coastal areas with a high proportion of the bottom area above the Secchi depth (Asec) generally have a high potential bioproduction and (2) that the bioproduction potential also depends on the substrate, i.e., on the bottom dynamic conditions prevailing in the coastal area, in short on the sedimentological characteristics, which are closely linked to the exposure. If the exposure is very high, the coastal area would generally be dominated by coarse sediments and bare rocks, if the exposure is limited, the coastal area may have a dense macrophyte cover and be dominated by fine sediments. Such areas should have a high bioproduction potential. This may be expressed in a simple manner in by Eq. 1, which defines the Index of Biological Value (IBV, dimensionless; see also Fig. (10)) from Asec (dimensionless) and the exposure (Ex, dimensionless).

$\mathrm{IBV}=10 \cdot \mathrm{Asec} /(0.1+\sqrt{\mathrm{Ex}})$

The exposure generally varies between 0.0001 and 3, i.e., with a factor of 30000 (see Fig. (11), which is based on data from, 478 Baltic coastal areas; see [43]; Asec varies between 0.06 and 1, i.e., with a factor of $15-20$. This has motivated the expression $(0.1+\sqrt{ } \mathrm{Ex})$ in Eq. 1. The latter expression will then vary between $15-20$, which means that variations in
Asec and in Ex are of equal importance for the index. IBV will vary between 0.1 and 100 (extremely valuable enclosed areas with a high percentage of the bottom area above the Secchi depth). A typical Baltic Sea coastal area would have an exposure of 0.2 (Fig. 11) and an Asec-value of 0.5, which gives an IBV-value of 10 . According to the categories suggested in Fig. (10), this would indicate a coastal area at the border between "productive" and "moderately productive". The class limits for IBV, 1, 10, 25 and 50 and the categories "extremely productive, very productive, productive, moderately productive and low-productive", can, of course, be discussed and this nomenclature is given here as a suggestion. Since Asec and Ex are easy to define and understand, also IBV is easy to apply in practice in coastal management. To determine Asec, one would need data from standard monitoring programs on the Secchi depth as well as a bathymetric map so that the hypsographic curve can be produced. To determine the exposure, one must define the boundary lines for the coastal area by means of the topographical bottleneck approach and determine the section area (At) and the enclosed coastal area (A). This can be done easily if digitized bathymetric information is available (see [43]).

Since hypsographic curves may not be accessible for certain coastal areas, one can also estimate Asec using Eq. 2, which was originally derived for lakes [44]. Eq. 2 gives Asec 


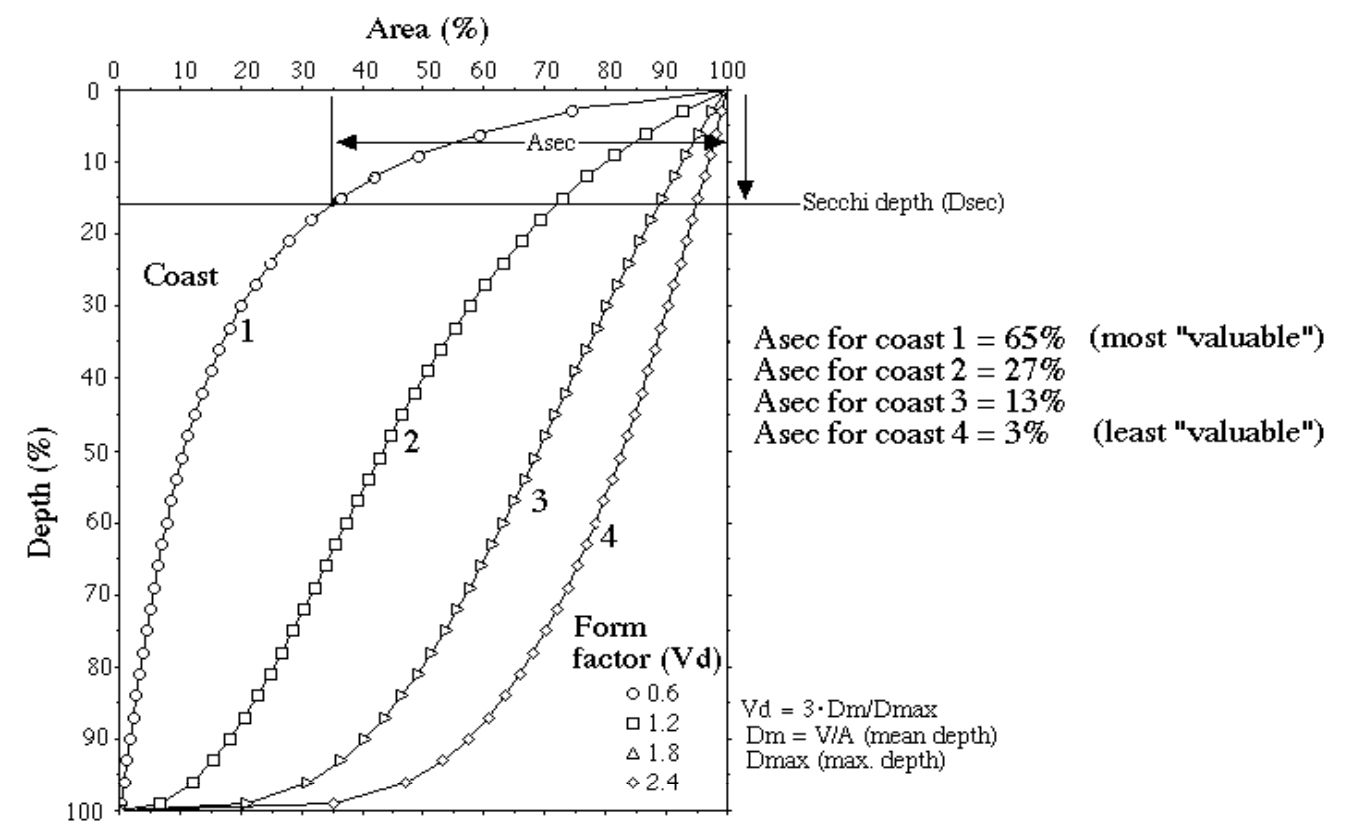

Fig. (8). Illustration of relative hyposographic curves (=depth-area curves) for four coasts with different forms (and form factor $=$ volume development $=\mathrm{Vd})$. The form influences the areas above the Secchi depth $($ Asec), which indicate the production capacity and "biological value" of the coastal system.

(in $\mathrm{m}$ ), as a function of the form factor, $\mathrm{Vd}$, the area of the coast (Area in $\mathrm{m}^{2}$ ) and the maximum depth of the coast (Dmax in $\mathrm{m}$ ). It would be interesting to try to derive a similar function also for open coastal areas, but that has been beyond the aim of this work. Eq. 2 has, however, been used to calculate Asec in Fig. (11G). This also means that it would probably be possible to create a more relevant frequency distribution and obtain better statistical information regarding Asec for these Baltic coastal areas, but for the present purpose these results may serve as examples illustrating the practical use of the IBV-index.

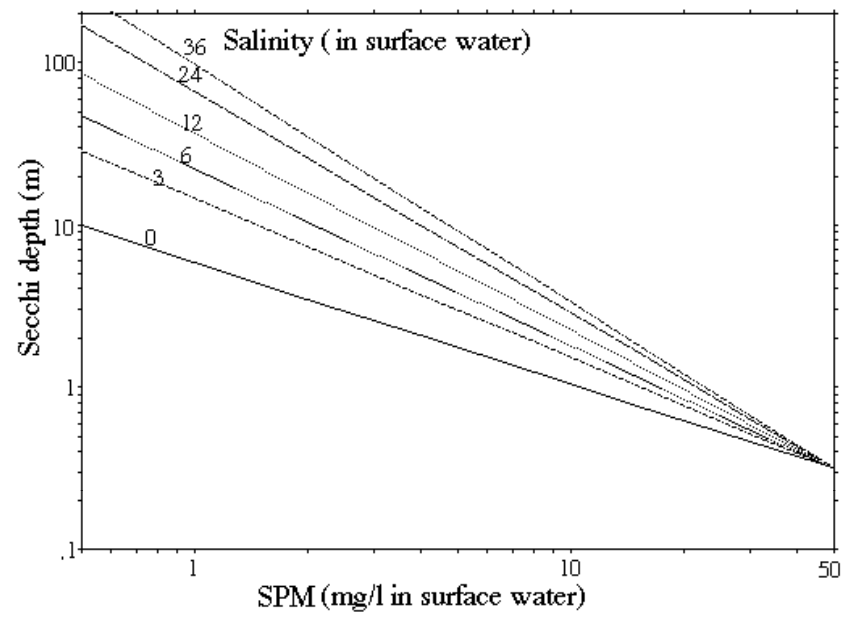

Fig. (9). Illustration of the relationship between Secchi depth, SPM in surface water and salinity in surface water (from [26]).

Asec $=$ Area-Area $\cdot(($ Dmax - Dsec $) /($ Dmax + Dsec $\cdot \operatorname{EXP}(3-$ $\left.\left.\left.\mathrm{Vd}^{1.5}\right)\right)\right)^{(0.5 / \mathrm{Vd})}$

Where EXP is the exponent and Dsec the Secchi depth. Deep, U-formed systems generally have smaller areas above the Secchi depth.

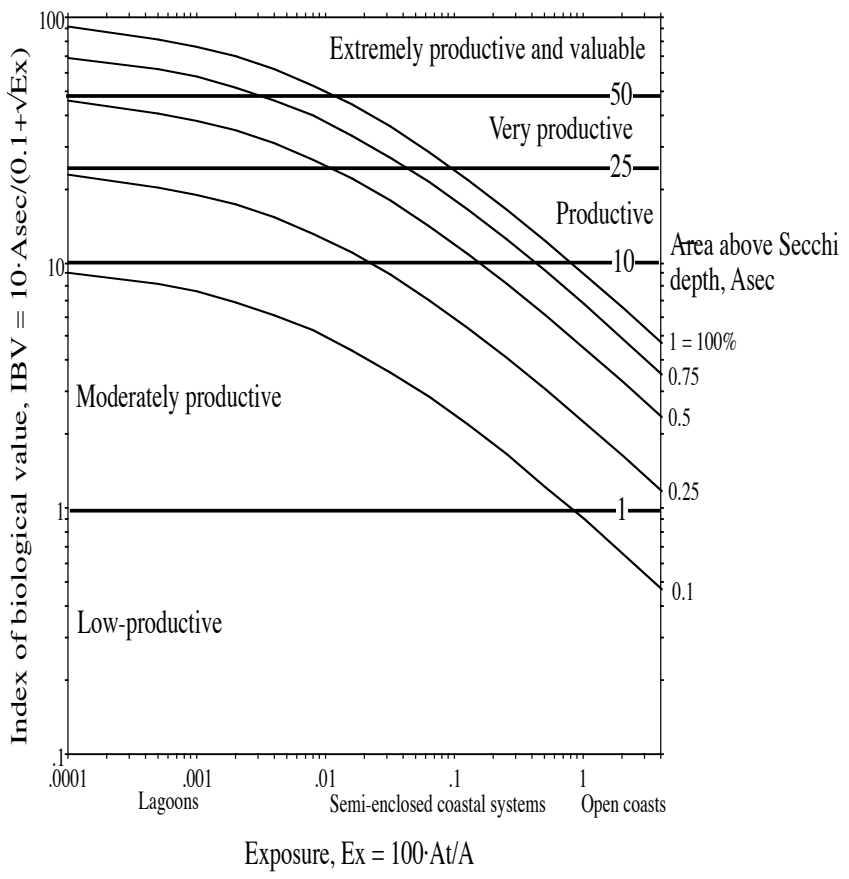

Fig. (10). Nomogram illustrating how the Index of Biological Value (IBV) is related to the exposure (Ex) and the area above the Secchi depth (Asec).

Fig. (11) gives frequency distributions and statistics (mean values, medians, standard deviations, minimum and maximum values) for (A) coastal area, (B), section area, (C) exposure, (D) mean depth, (E) maximum depth, (F) area above the Secchi depth (from Eq. 2) and (G) the requested Index of Biological Value calculated for 478 Baltic coastal areas. One can note that the IBV varies between 0.6 (lowproductive) to 68 (extremely productive); the frequency distribution is positively skewed and the mean value is 12.9 (productive coastal area) and the median 10.5 (also indica- 

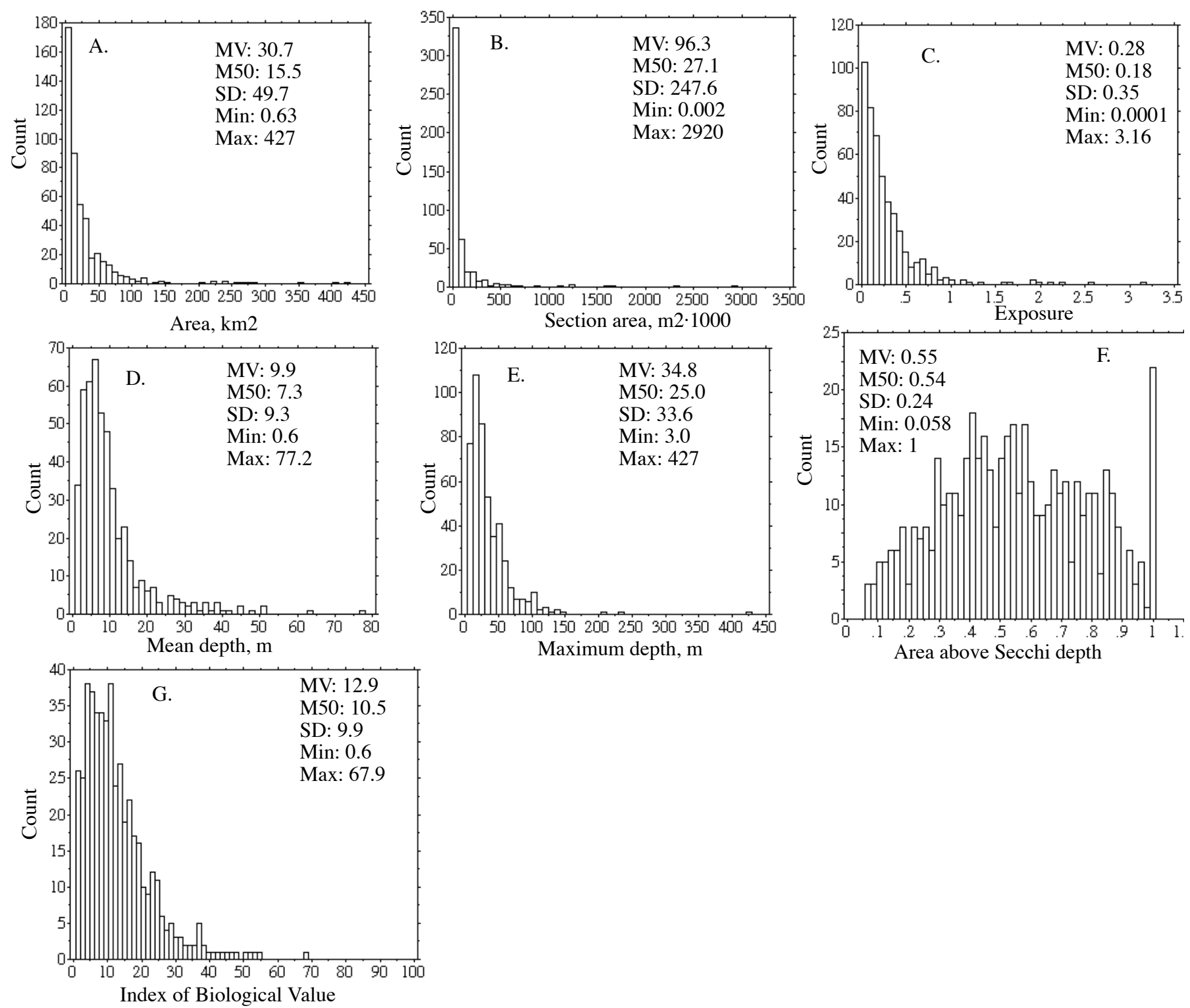

Fig. (11). Frequency distributions and statistics (mean values, medians, standard deviations minimum and maximum values) based on data from 478 Baltic coastal areas.

tive of productive conditions). There are $5(1 \%)$ extremely productive coastal areas (IBV $>50), 43(9 \%)$ very productive coastal areas $(25<\mathrm{IBV}<50), 209(43.7 \%)$ productive coastal areas $(10<\mathrm{IBV}<25), 214(63.0 \%)$ moderately productive coastal areas $(1<\mathrm{IBV}<10)$ and $7(1.5 \%)$ low-productive coastal areas $(\mathrm{IBV}<1)$.

Using geographical information systems (GIS) based on digitized bathymetric data, it is easy to apply these concepts and determine IBV for any given coastal area.

\section{CONCLUSIONS}

This work has motivated and introduced an index expressing the production potential or the biological "value" of coastal areas. Note that the class limits and categories defined in Fig. (10) should be regarded with due reservation. New data and information may motivate changes in the classes and the nomenclature. Evidently, much more could be done to critically test this approach for other systems cov- ering wider gradients in salinity and trophic status, Secchi depths and exposure.

This work may be considered as a steppingstone toward such goals.

Coastal areas of different size may have similar IBVvalues. From the perspective of regional, national or international sustainable management, it is, evidently, most important to try to maintain high IBV-values for the larger areas. The main threat to the bioproduction potential and the biological value, as expressed by IBV, is eutrophication, which lowers the Secchi depth and hence also Asec and IBV.

\section{REFERENCES}

[1] Rosenberg R. Eutrophication - the future marine coastal nuisance? Marine Pollut Bull 1985; 16: 227-231.

[2] Mann KH. Ecology of coastal waters. A systems approach: Blackwell Scientific Publications 1982; p. 322. 
[3] Sandberg J, Elmgren R, Wulff F. Carbon flows in Baltic Sea food webs - a re-evaluation using a mass balance approach. J Mar Syst 2000; 25: 249-60.

[4] Wallin M, Håkanson L, Persson J. Load models for nutrients in coastal areas, especially from fish farms (in Swedish with English summary). Nordiska ministerrådet: Nr 502 Copenhagen 1992; p. 207.

[5] Lundin LC. Water in Society. Sustainable water management in the Baltic Sea basin, The Baltic Univ. Progr: Uppsala Univ. 1999; p. 244.

[6] Lundin LC. The Waterscape. Sustainable water management in the Baltic Sea basin, The Baltic Univ Progr: Uppsala Univ 2000; p. 207.

[7] Lundin LC. River Basin Management. Sustainable water management in the Baltic Sea basin, The Baltic Univ. Progr: Uppsala Univ. $2000 ;$ p. 244.

[8] Wulff F, Rahm L, Larsson P, Eds. A systems analysis of the Baltic Sea. Springer-Verlag, Berlin: Ecolog Stud 2001; 148: p. 455.

[9] Diaz RJ, Solan M, Valente RM. A review of approaches for classifying benthic habitats and evaluating habitat quality. J Environ Manage 2004; 73: 165-81.

[10] Håkanson L, Bryhn AC, Blenckner T. Operational effect variables and functional coastal ecosystem classifications - a review on empirical models for aquatic systems along a salinity gradient. Int Rev Hydrobiol 2007; 92: 326-57.

[11] Vollenweider RA, Giovanardi F, Montanari G, Rinaldi A. Characterization of the trophic conditions of marine coastal waters with a special reference to the NW Adriatic Sea: Proposal for a trophic scale, turbidity and generalized water quality index. Environmetrics 1998; 9: 329-357.

[12] Redfield AC. The biological control of chemical factors in the environment. Am Scient 1958; 46: 205-22.

[13] Ryther JH, Dunstan WM. Nitrogen, phosphorus, and eutrophication in the coastal marine environment. Science 1971; 171: 1008-13.

[14] Nixon SW, Pilson I. Nitrogen in estuarine and coastal marine ecosystems. In: Carpenter EJ, Capone DG, Eds. Nitrogen in the marine environment. Academic Press: New York 1983; pp. 565-648.

[15] Ambio. Special issue. Marine eutrophication. Ambio 1990; 19: 102-76.

[16] Nixon SW. Marine eutrophication: a growing international problem. Ambio 1990; 3: 101 .

[17] Moldan B, Billharz S, Eds. Sustainability indicators. Wiley 1997; see http://www.icsu-scope.org/downloadpubs/scope58/.

[18] Aertbjerg G, Ed. Eutrophication in Europe's coastal waters. European Environment Agency, Topic report 2001; 7/2002, Copenhagen, pp. 86.

[19] Livingston RJ. Eutrophication processes in coastal systems. CRC Press: Boca Raton 2001; p. 327.

[20] Nielsen SL, Sand-Jensen K, Borum J, Geertz-Hansen O. Phytoplankton, nutrients and transparency in Danish coastal waters. Estuaries 2002; 25: 930-7.

[21] Rabalais NN, Nixon SW. Dedicated issue: Nutrient overenrichment in coastal waters: global patterns of cause and effect. Estuaries 2002; 25: 639-900.

[22] Bortone SA, Ed. Estuarine indicators. CRC Press: Boca Raton 2005; p. 531.

[23] Schindler DW. Recent advances in the understanding and management of eutrophication. Limnol Oceanogr 2006; 51: 356-63.
[24] Schernewski G, Wielgat M. A Baltic Sea typology according to the EC-Water Framework Directive: Integration of national typologies and the water body concept. Coastline Reports 4 2004; ISSN 09282734, 1-26.

[25] Pilesjö P, Persson J, Håkanson L. Digital bathymetric information for calculations of morphometrical parameters and surface water retention time for coastal areas (in Swedish). National Swedish Environmental Protection Agency (SNV: Solna, Sweden) 1991; Report no. 3916.

[26] Håkanson L. Suspended particulate matter in lakes, rivers and marine systems. The Blackburn Press: New Jersey 2006; pp. 319.

[27] Håkanson L, Boulion V. The Lake Foodweb - modelling predation and abiotic/biotic interactions. Backhuys Publishers Leiden 2002; p. 344 .

[28] Cummings KW. Trophic relations in aquatic insects. Ann Rev Entomol 1973; 18: 183-206.

[29] Brinkhurst RO. The benthos of lakes. Macmillan: London 1974; p. 189.

[30] Håkanson L, Rosenberg R. Practical coastal ecology (Praktisk kustekologi). SNV PM 1987, Solna 1985; p. 110 (in Swedish).

[31] Moen FE, Svensen E. Marine fish and invertebrates. AquaPress: Essex 2004; p. 608.

[32] Håkanson L. The influence of wind, fetch, and water depth on the distribution of sediments in Lake Vänern, Sweden. Can J Earth Sci 1977; 14: 397-412.

[33] Håkanson L, Eklund JM. A dynamic mass balance model for phosphorus fluxes and concentrations in coastal areas. Ecol Res 2007; 22: 296-320.

[34] Möller P, Pihl L, Rosenberg R. Fisk och bottendjur i grundområden i Bohuslän och Halland - en biologisk värdering. SNV PM 1985; 1911: 7-95.

[35] Vollenweider RA. Sichttiefe und production. Verhandlung Int Vereinig Limnologie 1958; 13: 142-43.

[36] Vollenweider RA. Beitrage zür kenntnis optischer eigenschaften der gewässer und primärproduktion. Mem Ist Ital Idrobiol 1960; 12: 201-44.

[37] Carlson RE. A trophic state index for lakes. Limno Oceanogr 1977; 22: 361-9.

[38] Carlson RE. More complications in the chlorophyll - Secchi disk relationship. Limnol Oceanogr 1980; 25: 379-82.

[39] Preisendorfer RW. Secchi disk science: Visual optics of natural waters. Limnol Oceanogr 1986; 31: 909-26.

[40] Kiefer DA, Austin RW. The effect of varying phytoplankton concentration on submarine transmission in the Gulf of California. Limnol Oceanogr 1974; 19: 55-64.

[41] Tilzer MM. Secchi disk - chlorophyll relationships in a lake with highly variable phytoplankton biomass. Hydrobiologia 1988; 162: 163-71.

[42] Nürnberg GK, Shaw M. Productivity of clear and humic lakes: nutrients, phytoplankton, bacteria. Hydrobiologia 1998; 382: 97112.

[43] Lindgren D, Håkanson L. Functional classification of coastal areas as a tool in ecosystem modeling and management. Manuscript, Inst. of Earth Sci: Uppsala Univ; 2008.

[44] Håkanson L. Water pollution - methods and criteria to rank, model and remediate chemical threats to aquatic ecosystems. Backhuys Publishers Leiden 1999; p. 299. 